\title{
Combined Effects of Simulated Waterlogging and Drought on Production of Hungarian Winter Wheat Varieties
}

\author{
Zsuzsanna FARKAS ${ }^{1}$ - Emese VARGA-LÁSZLÓ ${ }^{2}$ - Angéla ANDA ${ }^{3}$ - Gyula VIDA ${ }^{4}$ - \\ Balázs VARGA 5 \\ 1: Agricultural Institute, Centre for Agricultural Research, Hungarian Academy of Sciences, Martonvásár, \\ Hungary, University of Pannonia, Georgikon Faculty, Festetics Doctoral School, Keszthely, Hungary; farkas. \\ zsuzsanna@agrar.mta.hu \\ 2: Monsanto Hungária Ltd., Budapest, Hungary; emese.varga-laszlo@bayer.com \\ 3: University of Pannonia, Georgikon Faculty, Department of Meteorology and Water Management, Keszthely, \\ Hungary; anda-a@georgikon.hu \\ 4: Agricultural Institute, Centre for Agricultural Research, Hungarian Academy of Sciences, Martonvásár, \\ Hungary; vida.gyula@agrar.mta.hu \\ 5: Agricultural Institute, Centre for Agricultural Research, Hungarian Academy of Sciences, Martonvásár, \\ Hungary; varga.balázs@agrar.mta.hu
}

Keywords: simulated flooding, abiotic stress, plant physiology, Triticum aestivum L.

\section{Introduction}

The decreasing precipitation in combination with increasing temperature are the most important yield-limiting factors and these are threatening the food security worldwide (Daryanto et al., 2017). Drought is one of the most limiting stressors for cereals, including wheat, that harms the crop growth physiology and productivity (Fahad et al., 2017), it can reduce the amount of biomass more than $25 \%$ and causes a large crop failure (Zhang et al., 2018). Besides the deficit of rainfall, the unusually high amount of precipitation can also affect the plant growth negatively. Soil waterlogging affects $25 \%$ of the wheat plantation worldwide (Powell et al., 2012). Wheat can tolerate the waterlogging for different time period and its resistance depends on both the plant's maturity stage and the temperature (Ding et al., 2018).

The presented study aimed to determine the crop water demand and transpiration productivity of five cultivated winter wheat varieties. Furthermore, the investigation of the influence of waterlogging and drought occurring in the different stages of the plant growth.

\section{Materials and methods}

Five winter wheat varieties had been examined ('Mv Toborzó', 'Mv Mambó', 'Mv Karizma', 'Mv Pálma' and 'Bánkúti 1201') under controlled greenhouse conditions in Martonvásár, Hungary. Experimental design involved three treatments: a) (K; the plants received optimal water-supply constantly (soil relative water content $(\mathrm{SRWC}))=60 \%$ ), b) a waterlogging stress-treatment (SZ) in a four-leaf stage of the plants $(5 \mathrm{~cm}$ water coverage above the soil surface) and c) the second stress-treatment: the plants get both of the waterlogging at the early stage and in heading a drought stress (SZ+KAL) had been simulated by stopping the watering completely (till the soil water content dropped below 5\%). Five plants were planted in pots containing 10 litres homogenous soil mixture and every treatment were replicated three times. The most important parameter, the water use efficiency (WUE) was calculated by dividing the whole grain yield with total water usage during the vegetation period. Twoway ANOVA test was applied to determine the effects of the factors (water supply and genotype) and Tukey post hoc test was used to comparing the means. 


\section{Results and discussion}

The waterlogging significantly decreased the grain weight of 'Bánkúti 1201' and 'Mv Toborzó'; their measured values were $40 \%$ and $30 \%$ lower, respectively than of the control. Ding et al. (2018) have also found that waterlogging reduces the grain weight. As result of waterlogging treatment, the water uptake of plants has been significantly decreased in 'Bánkúti 1201' (10\%), although slightly increased in 'Mv Karizma', 'Mv Mambó' and 'Mv Pálma' $(6 \%, 12 \%, 22 \%$, respectively). According to Saraim et al. (2008), waterlogging resulted an increase in water uptake in wheats. We found that the combined treatment (waterlogging in early stage and drought by heading) significantly decreased the grain weight in every genotype. 'Bánkúti 1201' was the most susceptible to the combined stresses as the yield decreased with $73 \%$. The highest adaptive potential was observed in 'Mv Pálma' (38\% yield reduction). Ding et al. (2018) have also observed a significant decrease in grain yield of wheat as affected to waterlogging and drought stresses. As the effect of the combined treatment, the water use of 'Mv Pálma' did not change significantly, but in case of the other varieties, statistically significant reduction in water uptake was observed; 31\%, 27\% and 26\% in 'Mv Karizma', 'Bánkúti 1201' and 'Mv Toborzó', respectively. The waterlogging treatment resulted no changes in water use efficiency with one exception of genotype 'Mv Karizma'. On the other hand, the combined treatment resulted in a significant decrease in every studied variety.

\section{Conclusions}

We concluded that the treatments affected 'Bánkúti 1201 ' the most adversely, whereas 'Mv Pálma' and 'Mv Karizma' showed promising level of adaptability.

\section{Acknowledgement}

Our research costs were covered from GINOP-2.3.2.-15-2016-00029 (Multifunkcionálisan hasznosítható növények, mint alternatívák a fenntartható mezőgazdaság szolgálatában) project and TÉT_15-1-2016-0108 project.

\section{References}

Daryanto, S., Wang, L., Jacinthe, P.A. (2017): Global synthesis of drought effects on cereal, legume, tuber and root crops production: A review. Agric. Water Manag. 179: 18-33. doi: 10.1010/j.agwat.2016.04.022

Ding J., Huang Z., Zhu M., Li C., Zhu X., Guo W. (2018): Does cyclic water stress damage wheat yield more than single stress? Plos One. 13 (4): e0195535 doi: 10.1371/journal.pone.0195535

Fahad, S., Bajwa, A.A., Nazir, U., Anjum, S.A., Farooq, A., Zohaib, A., Sadia, S., Nasim, W., Adkins, S., Saud, S. (2017): Crop Production under Drought and Heat Stress: Plant Responses and Management Options. Front. Plant Sci. 8: 1147. doi: 10.3389/fpls.2017.01147

Sairam R., Kumutha D., Ezhilmathi K., Deshmukh P., Srivastava G. (2008): Physiology and biochemistry of waterlogging tolerance in plants. Biol Plant 52 (3):401-412. doi:10.1007/ s10535-008-0084-6

Zhang, J., Zhang, S., Cheng M., Jiang H., Zhang X., Peng, C., Lu X., Zhang M., Jin J. (2018): Effect on drought on agronomic traits of rice and wheat: a meta-analysis. Int. J. Environ. Res. Public Health. 15 (5): E839. doi: $10.3390 /$ ijerph 15050839 